IZA DP No. 8539

Workplace Democracy and Job Flows

Guillermo Alves

Gabriel Burdin

Andres Dean

October 2014

Forschungsinstitut

zur Zukunft der Arbeit

Institute for the Study

of Labor 


\title{
Workplace Democracy and Job Flows
}

\author{
Guillermo Alves \\ Universidad de la República \\ and Brown University \\ Gabriel Burdin \\ Universidad de la República \\ and IZA \\ Andres Dean \\ Universidad de la República
}

\section{Discussion Paper No. 8539 \\ October 2014}

\author{
IZA \\ P.O. Box 7240 \\ 53072 Bonn \\ Germany \\ Phone: +49-228-3894-0 \\ Fax: +49-228-3894-180 \\ E-mail: iza@iza.org
}

Any opinions expressed here are those of the author(s) and not those of IZA. Research published in this series may include views on policy, but the institute itself takes no institutional policy positions. The IZA research network is committed to the IZA Guiding Principles of Research Integrity.

The Institute for the Study of Labor (IZA) in Bonn is a local and virtual international research center and a place of communication between science, politics and business. IZA is an independent nonprofit organization supported by Deutsche Post Foundation. The center is associated with the University of Bonn and offers a stimulating research environment through its international network, workshops and conferences, data service, project support, research visits and doctoral program. IZA engages in (i) original and internationally competitive research in all fields of labor economics, (ii) development of policy concepts, and (iii) dissemination of research results and concepts to the interested public.

IZA Discussion Papers often represent preliminary work and are circulated to encourage discussion. Citation of such a paper should account for its provisional character. A revised version may be available directly from the author. 


\section{ABSTRACT}

\section{Workplace Democracy and Job Flows}

This paper investigates the relationship between workplace democracy and job flows (net job creations, gross job creations and destructions) by comparing the behavior of workermanaged firms (WMFs) and conventional firms. The empirical analysis relies on high frequency administrative firm-level panel data from Uruguay over the period April 1996-July 2009. The main findings of the paper are that (1) WMFs exhibit much more stable job dynamics than CFs; (2) both types of firms have decreasing in age and increasing in size gross job creation profiles; (3) there are heterogeneous employment regimes within WMFs: high job creation and destruction rates of hired workers and low job creation and destruction of members. This paper contributes to the literature on the role of institutions in shaping job flows. Our results may have important implications for the understanding of the allocative efficiency effects of worker participation.

JEL Classification: D21, J54, J63

Keywords: job flows, worker-managed firms

Corresponding author:

Gabriel Burdin

Instituto de Economia

Universidad de la Republica

Joaquín Requena 1375

11200, Montevideo

Uruguay

E-mail: gburdin@iecon.ccee.edu.uy

\footnotetext{
* We are grateful to Carlos Casacuberta and to seminar and conference participants at the 17th Conference of the International Association for the Economics of Participation and Instituto de Economía (IECON), Facultad de Ciencias Económicas y de Administración, Universidad de la República for their useful comments. Usual disclaimer applies.
} 


\section{Introduction}

The flow approach to labor markets is considered a hallmark of modern empirical labor economics (Cahuc, 2014). The availability of new data sources has allowed researchers to split up net employment variations into both job flows (job creations and job destructions) and worker flows (hirings and separations). A key result emerging from this literature is that commonly used net employment change statistics may mask the simultaneous presence of large numbers of jobs created and destroyed in a given period of time. Job flows appear to be quite large and of similar magnitude among both developed and developing countries (Davis et al., 1998, 2006; Haltiwanger et al., 2014).

While previous studies have focused on how several firms' characteristics, such as age, size, and industry location, correlate with job flows, there is no evidence on whether firm-level institutions facilitating worker participation affect the pace of job creation and destruction. The real-world organization of firms reveals the existence of different participatory arrangements, such as employee consultation, work councils, codetermination and worker-managed firms. ${ }^{1}$ In spite of the growing interest among policymakers in promoting employee information, consultation and representation rights within firms ${ }^{2}$, very little is known about the microeconomic behavior associated with those institutions.

This paper investigates for the first time the effect of workplace democracy on job flows by comparing the behavior of worker-managed firms and conventional firms (hereafter respectively WMFs and CFs) in Uruguay over the period April 1996-July 2009. The empirical analysis relies on monthly firm-level panel data from social security administrative records. We investigate (1) whether participatory workplace institutions affect job flow indicators (net job creations, gross job creations and destructions), and (2) whether worker participation mediates the effect of the macroeconomic cycle as well as of firms' size and age on job flows.

The focus on WMFs is interesting due to several reasons. First, while CFs are ultimately controlled by capital suppliers, WMFs are defined as enterprises in which the workforce enjoys full control rights (Dow, 2003). This type of firms can be considered as the most radical implementation of worker participation in contemporary economies, combining profit sharing with full workers' control over firms' decision making. Moreover, the employment decisions of WMFs have attracted attention of economists since the late 1950s. The basic neoclassical model assumes that WMFs maximize revenue per worker rather than total profits and predicts that they would not respond in the usual way to changes in the product price, reducing the level of employment and output when

\footnotetext{
${ }^{1}$ According to Bryson et al. (2012), around one third of European workplaces with 10 or more employees have a trade union or works council body in place. Worker-managed firms are rare in most economies, even though certain regions exhibit a high concentration of this type of firms. For instance, WMFs account for $13 \%$ of economic activity in the northern Italian province of Emilia Romagna and $8 \%$ of industrial gross value added (and $4 \%$ of overall gross value) in the Basque Country, Spain, where the Mondragon Cooperative Corporation is located (Arando et al., 2012).

${ }^{2}$ This seems particularly true in the European context, as suggested by several European Union Directives (see, for instance, Hall and Purcell, 2011).
} 
the market price increases (Ward, 1958) ${ }^{3}$. Even though this extreme implication of the model has not been empirically confirmed, there is, however, ample evidence that employment responses to demand shocks are less elastic in WMFs compared with conventional firms (Craig \& Pencavel, 1992; Pencavel et al., 2006; Burdín \& Dean, 2009; Pencavel, 2013). ${ }^{4}$ Nevertheless, all available studies have focused on net employment variations.

The central findings of the paper can be summarized in five main facts. First, WMFs exhibit much more stable job dynamics than CFs. Both gross creation and destruction rates for WMFs are in the order of a half of those of CFs. Second, although net job creation in continuing CFs and WMFs follows the macroeconomic cycle as expected, creation of new WMFs during recession years makes net employment creation in WMFs much less procyclical than in CFs. This points to an interesting job stabilizer role of WMFs. Third, in the last years of the period when the Uruguayan economy was booming with GDP growth rates over $5 \%$ on average, both types of firm exhibited unprecedentedly high rates of gross job creation and destruction pointing to the existence of strong efficiency-improving labor reallocation. This is of great relevance since it indicates that job stability in WMFs does not imply incapacity of participating in economy wide efficiency-improving labor reallocation processes. Fourth, both types of firms have decreasing in age and increasing in size gross job creation profiles. In terms of job destruction rates, both types have a decreasing age profile in the cross-section but when looking at within firms' profiles in the panel firms seems to destroy more employment as they get older. This might be associated with most of the job destruction observed in the cross section being done by very young firms which die young and do not affect the estimation of the age profile in the panel regressions. Fifth, a relevant fact for WMFs is that their characteristic stable job flows pattern holds for the majority of their workers who democratically own the firm (members) and not for the minority which do not enjoy membership rights (employees). Gross job flow rates for the latter are even higher than for employees working for CFs.

This study contributes both to the literature on job flows and worker participation in three distinct ways. First, the study expands the existing literature on employment responses of WMFs which, as mentioned, has been previously restricted to studying net employment changes. The application of the job flow approach allows to disentangle whether the observed differences between WMFs and conventional firms in net job flows are attributable either to job creations or destructions (or both). By investigating gross job flows, this paper provides additional insights into the specific employment adjustment mechanisms in participatory workplaces. We also separate job flows associated with the behavior of incumbent firms from those related to firms' entries and exits. Second, this study provides one of the first empirical attempts to investigate the role of worker participation as a mediator factor between firm's attributes and job flows. Finally, by computing separate job flows indicators for both members and hired employees in WMFs, we identify two

\footnotetext{
${ }^{3}$ The model has not proved to be robust to several theoretical variations. For instance, it does not necessarily hold in the case of multiproduct WMFs or when the production process involves other variable inputs apart from labor. It has also been argued that worker- members will be reluctant to vote for layoffs because, in a WMF in which members are equally treated, everybody faces similar probabilities of being selected for dismissal (Moene, 1989).

${ }^{4} \mathrm{By}$ contrast, wages appear to be more volatile in WMFs than in CFs.
} 
sharply different employment dynamics' regimes within this type of organizations. On one hand, employment flows of hired labor are characterized by both high job creation and destruction rates. On the other, the dynamics of the members' jobs exhibit both low job creation and destruction. Despite having very different implications, both regimes (the one for employees and the one for members) are consistent with low net employment creation and, hence, are undistinguishable if one solely relies on net employment variations.

The rest of the paper is organized as follows. Section 2 briefly discusses the job flow literature, emphasizing stylized facts related to how firm's characteristics correlate with job flows and linking it with previous work on the employment effects of worker participation. Section 3 provides background information on Uruguayan WMFs and describes the data and the empirical methodology. In section 4 , we present the main findings of the paper. Section 5 concludes with some final remarks.

\section{Related literature}

The fact that net employment changes may mask large job and worker flows has been a major discovery of empirical studies based on the flow approach to labor markets (Davis et al., 2006). Previous studies have been focused on how firm-level attributes correlate with job flows in developed countries (see, for instance, Bassanini, 2010). A partial exception is Haltiwanger et al. (2014) who provides evidence of job flows for 16 industrial and emerging economies, including some Latin American and transition countries. Based on harmonized micro-data, they find that annual job flows are large in most countries and that size-industry effects account for half of the overall sample variability in job flows. Interestingly, their study reveals a substantial unexplained residual variation, suggesting the potential role of labor market institutions and business environment conditions in shaping cross-country differences in job flows.

Closely related to the present study, Haltiwanger et al. (2013) analyze the relationship between firm size and employment growth and explore the mediating role of firm age. Using data from US private nonagricultural firms, the authors dispute the popular belief that small business account for the most jobs. They find that after controlling for firm age there is no systematic inverse relationship between net employment growth rates and firm size, emphasizing the crucial role of firm births and the fact that new firms are usually smaller than incumbents.

The role of institutions in shaping the pace of job flows has been studied in a lesser extent. There is some evidence that labor markets characterized by more stringent employment protection legislation, higher unemployment benefits and more coordinated wage bargaining systems exhibit lower job flows (Gomez-Salvador et al., 2004; Cahuc, 2014). Casacuberta et al. (2005) analyze annual job flows in Uruguay during the period 1982-1995 using firm survey data and find that highly unionized industries exhibit higher job creation and lower job destruction rates. However, there is very little research done examining the relationship between corporate governance institutions 
- including those guaranteeing workers the right to exercise either partial of full control over the firm's decisions - and job flows.

Some studies analyze employment adjustments in worker-managed firms, in which the workforce enjoy full control rights, compared with conventional firms. The main conclusion of this line of research is that worker participation is associated with more stable employment relationships (Craig and Pencavel, 1992; Pencavel et al., 2006; Burdin and Dean, 2009). However, this literature has mainly relied on net employment changes comparisons. There is also some research on the German codetermination system in which employees have representation on the board of directors and have the right to form establishment-level work councils. Work councils seem to reduce labor fluctuations (Addison et al., 2001). Regarding their effect on employment growth, the literature has reached conflicting results (Addison et al., 2001; Addison \& Teixeira, 2005; Jirjahn, 2010). None of these studies provide a detailed analysis in terms of job flows.

\section{Data and methodology}

\subsection{Data and background information on Uruguayan WMFs}

In Uruguay, WMFs are defined as firms legally registered as Producer Cooperatives in which the ratio between permanent employees and members does not exceed 20\%. Despite the fact that WMFs are allowed to hire temporary employees in response to seasonal demand changes, they must comply with the maximum level of hired workers to be entitled to certain tax advantages. In particular, WMFs are exempted from paying the employer payroll tax to social security. Furthermore, the law requires a minimum of six members in order to register a new cooperative firm.

Even though certain key organizational features are predetermined by law, WMFs are free to decide upon a broad range of associational rules. Regarding their governance structure, WMFs have a General Worker Assembly that selects a Council (which usually selects the managers) to supervise the daily operations. Each member of the assembly has only one vote, regardless of her capital contribution to the firm. Uruguayan WMFs mainly operate under a collective ownership regime.

This study is conducted using an unbalanced panel of Uruguayan firms, consisting of monthly firm-level observations over the period April 1996 - July 2009. The data set is based on social security administrative records provided by Banco de Previsión Social (BPS), which is the public agency in charge of social security affairs in Uruguay. The data set covers the entire population of firms registered as Producer Cooperatives (PCs) and conventional firms in 112 3-digit sectors in which at least one $\mathrm{PC}$ was registered during that period. The available firm-level information includes firms' industry class (5 digits, ISIC, fourth revision), employment, and average wage, distinguishing members and nonmembers in the case of PCs. ${ }^{5}$

${ }^{5}$ Employment variables refer to formal employment. the fraction of informal workers is quite low in uruguay compared to other developing countries (20\% in 2014). 
Previous studies on Uruguayan WMFs have pointed out that not all firms registered as PCs should be considered as WMFs. Specifically, in many firms legally registered as PCs the majority of the workforce has no control over firm decisions (Burdín \& Dean, 2009; Burdín, 2014; ?). We distinguish WMFs from the total population of producer cooperatives using information on the employee-to- member ratio. More precisely, we define WMFs as those firms registered as PCs where this average lifetime ratio is no greater than $20 \%$ and exclude observations on PCs the computed ratio is greater than $20 \% .6$

\subsection{Methodology}

The paper will work with three main concepts of job flows: gross job creation, gross job destruction and net job creation. As in Davis, Haltiwanger, and Schuh Davis et al. (1998), let's start by defining $X_{t}$ as the number of jobs of a firm at time $t$, which in our case will be the month.

With $\Delta X_{t}=X_{t}-X_{t-1}$ being the first difference operator on the number of jobs at time $t$, gross job creation for a given set of firms $S$ is defined as:

$$
C_{t}=\sum_{S^{+}} \Delta X_{t}
$$

Where $S^{+}$is the subset of firms with $\Delta X_{t}>0$. Analogously, Gross job destruction is given by:

$$
D_{t}=\sum_{S^{-}}\left|\Delta X_{t}\right|
$$

Net job creation is simply the difference $N_{t}=C_{t}-D_{t}$. Job flows become more meaningful when expressed as rates on the existing stock of jobs, which is usually done by dividing the absolute job flows above by the average number of jobs in periods $t$ and $t-1$ :

$$
Z_{t}=0.5\left(X_{t}+X_{t-1}\right)
$$

Gross job creation, gross job destruction and net job creation rates for a given firm are, respectively $^{7}$ :

$$
c_{t}=\frac{C_{t}}{Z_{t}}, \quad d_{t}=\frac{D_{t}}{Z_{t}}, \quad n_{t}=\frac{N_{t}}{Z_{t}}
$$

\footnotetext{
${ }^{6}$ Employment variables refer to formal employment. The fraction of informal workers is quite low in Uruguay compared to other developing countries (20\% in 2014).

${ }^{7}$ One additional job flow concept used in the literature is that of job reallocation. The job reallocation (rate) is given by the sum of gross job creation (rate) and gross job destruction (rate) and is interpreted as a summary measure of the intensity of job flows.
} 
These rates can be conveniently aggregated for any set $S$ of firms of a certain age, size, industry or year (or combinations of those) as sum-weighted averages of each firm $i$ rates:

$$
\begin{gathered}
c_{S, t}=\sum_{i \in S} \frac{Z_{i, t}}{Z_{S, t}} c_{i, t} \\
d_{S, t}=\sum_{i \in S} \frac{Z_{i, t}}{Z_{S, t}} d_{i, t} \\
n_{S, t}=\sum_{i \in S} \frac{Z_{i, t}}{Z_{S, t}} n_{i, t}
\end{gathered}
$$

In some parts of the empirical exercise for example, we will be looking at job flow rates which are anual averages. Obtaining these anual averages is a special case of computing the aggregate rates above when $\mathrm{S}$ is the set of firms belonging to a given year.

\section{Results}

\subsection{Job flows trends}

Between 1996 and 2009 conventional firms in Uruguay created and destroyed each month a number of jobs equivalent to roughly $4 \%$ of the existing stock of jobs (see Table 2). The number of jobs created was actually higher than those destroyed, yielding an average net rate of job growth of $0.3 \%$ each month. WMFs had on average much lower gross rates of job creation and destruction in comparison with $\mathrm{CF}$ in the period, with magnitudes that are less than a half of those exhibited by CFs. Although differences in gross rates between both types of firms are sharp, the difference in terms of net creation is small with WMFs exhibiting a net monthly rate of $0.17 \%$. In other words, for a given amount of net creation CFs create and destroy a much higher number of jobs than WMFs.

Figure 1 shows how the pattern of net job creation for CFs followed strikingly closely the economy's growth rate. The general evolution of Uruguay's economy in the period can be described with a cyclical pattern of growth, crisis and growth: the economy grew between 1996 and 1998, went through a harsh recession between 1999 and 2002 and a period of several years of high growth followed. Net job creation for WMFs also followed the general evolution of the economy, but less tightly, in particular during the years of economic crisis. While CFs had net job destruction during four consecutive years between 1999 and 2002, WMFs created more jobs than what they destroyed during those years and only had slightly negative job growth in 2002, which was the worst year of the crisis. 
The evolution of gross job creation and destruction for each type of firm in Figure 2 shows some interesting patterns. In this graph the vertical difference between creation and destruction rates is the average monthly net job creation rate in a given year. Keeping this in mind, we can explain the evolution of net job growth described in Figure 1 by looking at the differences between job creation and destruction rates in Figure 2. Job creation in both types of firms anticipated the crisis and fell in the first years of the period while the economy was still growing. The job creation rate for CFs fell below a relatively stable job destruction rate in 1999 and stayed below until the economy recovered in 2003.

It is interesting to note how the destruction rate grew almost ten points in the final years of the period when the economy was growing rapidly. This pictures a highly dynamic labor market during these years, which required lots of job destruction to accommodate the high job creation rates in the booming Uruguayan economy. Most importantly, given the main question of the paper on the relative performance of WMFs with respect to CFs, this upward shift in the magnitudes of gross job creation and destruction occurred for both types of firms. It seems that although WMFs exhibited a much more stable pattern than CFs, they were capable of joining the higher economic dynamism and economy wide reallocation of labor by increasing their rates of job creation and destruction.

\subsection{Job flows due to firms' entries and exits}

In Table 2 we decompose job creation and destruction rates by how much they were due to firms' entries and exits and how much it was job creation and destruction by incumbent firms. We draw three important conclusions from these numbers in Table 2. First, for both types of firms most of job creation and destruction is not due to the dynamics of firms entering and exiting the market but corresponds to job flows of incumbent firms' job dynamic. Second, since job creation and destruction rates due to this motive are relatively similar for both types of firms and overall job creation and destruction are much higher for CFs, this means that firms' exits and enters are more relevant in explaining absolute job dynamics in WMFs than in CFs. ${ }^{8}$

A third big fact to note from Table 2 is that the result referred above on positive net creation by WMFs during the recession years corresponds entirely to creation of new firms. While negative net creation in CFs between 1999 and 2003 is explained both by net exit of firms and net destruction of jobs by continuing firms, in WMFs there was positive net job creation due to jobs created by new firms outnumbering jobs destroyed by firms exiting the market. This fact points to the creation of new WMFs having a job stabilizer role during recessions with unemployed workers getting together to create new firms. ${ }^{9}$

Before turning to the regression analysis, we can summarize a general picture in which both

\footnotetext{
${ }^{8}$ Firms' entries account for $16 \%$ and $30 \%$ of total job creation in CFs and WMFs respectively. Job destruction due to firms' exits represent $16 \%$ and $25 \%$ of total job destruction in CFs and WMFs.

${ }^{9}$ This includes workers forming a new WMF by "recovering" the CF they used to work for.
} 
types of firms exhibited a high dynamism in terms of job creation and destruction in the period under analysis. The macroeconomic cycle played a fundamental role in explaining the dynamics of job creation and destruction in CFs, which can be seen as a rather mechanical result given that these firms constitute the large majority of the economy. The macro cycle also mattered a lot for WMFs but in a less straightforward way. While continuing WMFs exhibited milder negative net job creation during the recession, creation of new WMFs during these years led to overall positive net job creation. Finally, job reallocation rates (defined as the sum of creation and destruction) peaked during the recent economic boom, reaching unprecedentedly high values, which may have important implications in terms allocative efficiency and the growth potential of the Uruguayan economy.

\subsection{Regression analysis}

The simple comparison of unconditional means by types of firms above seems to indicate that WMFs are less dynamic than CFs in terms of both job creation and job destruction. The regression analysis will extend the analysis in two directions. First, it will reassess the question on the relative performance of WMF in terms of job dynamics by controlling for firm age, size and industry. Secondly, it will tell us how observable firms' characteristics such as age, size and industry correlate with job creation and destruction for each type of firm. Previous research has documented that younger firms tend to create and destroy more (Haltiwanger, Jarmin and Miranda 2013) and that job creation and job destruction rates tend to vary a lot by industry. The relationship between net job growth and firm size appears to be quite complex. Most studies have shown an inverse relationship between net job growth and firm size (see, for instance, Neumark, Wall, and Zhang, 2011), but this correlation vanishes once firm age controls are included (Haltiwanger et al., 2013). Our aim is to analyze if these stylized facts hold when we look at different organizational forms: Do WMFs have the same size and age profile than CFs in terms of job creation and job destruction?

We begin by estimating a set of fully non-linear regressions of the job flow rates on 9 dummies for age, 7 dummies for size, 4 industry dummies and one dummy for each of the calendar years in the sample. ${ }^{10}$ In Figure 4 we follow Haltiwanger, Jarmin and Miranda (2013) and plot the partial effects of each age dummy on net creation (with their respective confidence intervals) by type of firm when holding size, industry and year composition constant at their means. ${ }^{11}$ Due to the underlying fully saturated dummy variable regression model we can interpret these partials as being cell by cell net creation rates averages of each of the rates.

Figure 5 shows a decreasing and strongly non-linear relationship between firms' age and both gross job creation and destruction rates. Also, for both types of firm destruction rates are above creation rates for all age groups beyond the first year of life, which means that most of net job

\footnotetext{
${ }^{10}$ Age dummies are 1, 2-3, 4-5, 6-7, 8-9, 10-11, 12-13, 14-16, 17 and more years. Size dummies are 1, 2-4, 5-10, 11-20, 21-50, 51-100, 101 and more employees.

${ }^{11}$ These partial effects can be computed either by running separate regressions for each type of firm or one single regression interacting all the covariates with type of firm.
} 
creation is done by very young firms during the first year of life. It is also worth noting that WMFs do have significantly lower creation and destruction rates than CFs for all ages, which confirms the general picture previously given above by the simple comparison of unconditional means.

Table 3 presents regression results that evaluate the magnitude and significance of the partial correlations of each of the three job flow rates with the set of available observable characteristics. The first three columns show results from a regression of each of the three rates on a quadratic on size and age, interactions of these with a WMF dummy, plus industry and year dummies. These first columns take a cross-section approach to the data such that we can look at correlations of observables that do not vary within each firm, such as industry and firm type. Estimates reported in Columns 4 to 6 go further and exploit the panel structure of the data. This allows us to look at partial correlations of job flow rates with age and size within firms.

The results in Table 3 confirm the patterns by age described above and add some interesting patterns by size and industry. First, bigger firms have higher net and gross creation rates, both in the cross section and in the panel regressions, with quadratic coefficients indicating the existence of a concave relationship between size and job creation. ${ }^{12}$ Although we saw that job flow-age patterns don't vary by type of firm, the relationship between job creation and size does differ between WC and CF. Job creation grows more with firm size for WC than for CF and the relationship is also more concave.

\subsection{Job flows by workers' status in WMFs}

Previous works on WMFs in Uruguay have documented the pattern, mentioned above, of greater employment stability of this type of firms in terms of net employment dynamics (Burdin \& Dean 2009). However, this hides another interesting pattern; WMFs tend to adjust to shocks by adjusting the number of non-member employees rather than hiring or firing members. This can be clearly seen on Figure 3, where job creation and destruction rates are much higher for WMF's employees than for members. Burdin \& Dean (2009) have shown that net employment in WMFs is relatively inelastic to changes in output prices, both for members and employees. Putting our findings together with theirs leads to a picture in which employee jobs in WMF are not more dynamic in terms of net job movements but net rates hide strong movements in terms of creation and destruction.

We also analyze whether there is any difference in the firm age profile of net employment creation of members compared to hired workers within WMFs. Similarly to results reported in the previous section, in Figure 6 we plot the partial effects of each firm age dummy on net creation, separating members' and employees' job creation and holding size, industry and year composition constant at their means. Figure 6 shows a decreasing relationship between firm age and net employment creation for both members and employees. As shown for total employment, most of net job creation

\footnotetext{
${ }^{12}$ In the panel regression the coefficient is positive but not significant for gross job creation and negative for job destruction.
} 
is done by young firms and no clear differential pattern between members and employees emerges from the Figure. Even though rather imprecisely estimated, net creation rates of employees appear to be greater than net creation of members during most of the WMF lifecycle. In addition, the decreasing age-profile of net creation of employees is non-monotonic: it decreases with firm age until age 6-7 and then increases. Net creation of members decreases sharply until age 2-3 and then remains stable. The observed difference between net creation of members and employees in WMFs suggests that the employee-to-member ratio increases as the firm get older. ${ }^{13}$

\section{Conclusions and discussion}

According to the results presented in this paper, firm level institutions regarding worker participation seem to play an important role in determining the strength of job flows and their relationship with the macroeconomic cycle. Worker-managed firms, the most extreme form of worker participation, create and destroy significantly lower amounts of jobs than conventional firms in order to achieve a certain net job change. The gap in job dynamics between both types of firms did not change a lot along the pronounced macroeconomic cycle experienced recently by the Uruguayan economy. The cycle did bring differences in terms of net job creation. The set of WMFs had positive net job creation during the worst years of a deep macroeconomic crisis because several new firms were created. Interestingly, we document heterogeneous employment regimes within WMFs. On one hand, employment flows for hired labor are characterized by both high job creation and destruction rates. On the other, the dynamic of members' jobs exhibits both very low job creation and destruction rates. Similarly to Haltiwanger, Jarmin and Miranda (2013), the paper documents a strongly decreasing and non-linear relationship between job flow rates and firm age. This pattern holds for both types of firm.

Our results may have implications in terms of the comparative performance of both types of firms and also shed light on the potential effects of more limited participatory initiatives at the firm level, such as employee consultation, representation, and codetermination. The ease with which firms are able to expand or reduce employment is usually recognized as a crucial indicator of labor market health, and, more importantly, as a determinant of aggregate productivity (Bartelsman et al., 2013). According to this literature, recessions may have the positive side effect of reallocating resources from less productive to more productive firms. At the macro level, our results suggest that worker participation reduces the pace of labor reallocation which might be productivity-damaging if a significant fraction of firms adopt this type of arrangements. ${ }^{14}$ At the firm level, the more rigid employment policies implemented by WMFs may prevent productivity gains associated with the more intense use of firings and hirings as both selection and disciplinary devices (see, for instance,

\footnotetext{
${ }^{13}$ This result does not necessarily confirm the degeneration hypothesis in Ben-Ner sense (Ben-Ner, 1984). For instance see ?.

${ }^{14}$ For instance, the government may impose by law the obligation of shareholders to extend control rights to employees.
} 
Bloom and Sadun, 2012). This may offset (at least partially) commonly emphasized productivity advantages associated with worker participation, resulting from greater employee motivation, lower monitoring costs and higher investment in firm-specific skills.

On the other hand, the process of labor reallocation may also involve substantial costs, particularly during recessions. For instance, workers may have firm or industry-specific skills or face substantial transaction costs in changing jobs (Furubotn \& Wiggins, 1984). Under these conditions, informational asymmetries between labor and management in conventional firms can produce inefficient social outcomes. Management may have incentives to misinform workers about the situation of the enterprise and to use this information strategically. For instance, if managers do not have the obligation of informing and negotiating mass redundancy plans with employees -as they would in participatory workplaces- employees' ideas regarding alternative cost-saving solutions that management fails to see are less likely to be considered. Participatory arrangements may mitigate inefficiencies associated with asymmetric information and employer ex-post opportunism. In a participatory firm, wage moderation might be agreed upon in exchange for job preservation and the promise that wage concessions in bad times will be compensated with higher wages in good times. Such a promise may not be credible in the absence of employee information and participation, as managers cannot credibly commit not to distort information ex-post and renege on contracts (Dow 2003, p254). This bargaining failure may result in plant closings, entailing potentially allocational inefficiencies. Finally, workers value job stability in itself. Then, although greater job stability might entail productivity losses in terms of misallocation, it probably has a welfare enhancing effect in terms of higher workers' utility. ${ }^{15}$

\footnotetext{
${ }^{15}$ The impact of job insecurity on workers' well being has been analyzed by many studies. See, for instance, Clark et al (2009) and Otterbach \& Sousa-Poza (2014).
} 


\section{References}

Addison, J. T., Schnabel, C., \& Wagner, J. (2001). Work councils in germany: Their effects on establishment performance. Oxford Economic Papers, 53(4), 659-94.

Addison, J. T. \& Teixeira, P. (2005). The effect of works councils on employment change. GEMF Working Paper 2005-06, GEMF - Faculdade de Economia, Universidade de Coimbra.

Arando, S., Gago, M., Podivinsky, J. M., \& Stewart, G. (2012). Do labour-managed firms benefit from agglomeration? Journal of Economic Behavior \& Organization, 84 (1), 193-200.

Bartelsman, E., Haltiwanger, J., \& Scarpetta, S. (2013). Cross-country differences in productivity: The role of allocation and selection. American Economic Review, 103(1), 305-34.

Bassanini, A. (2010). Inside the perpetual-motion machine: cross-country comparable evidence on job and worker flows at the industry and firm level -super- $\dagger$. Industrial and Corporate Change, $19(6), 2097-2134$.

Ben-Ner, A. (1984). On the stability of the cooperative type of organization. Journal of Comparative Economics, 8(3), 247-260.

Bloom, N. \& Sadun, R. (2012). The organization of firms across countries. The Quarterly Journal of Economics, 127(4), 1663-1705.

Bryson, A., Forth, J., \& George, A. (2012). Workplace employee representation in europe. Technical report, Eurofound.

Burdín, G. (2014). Are worker-managed firms more likely to fail than conventional enterprises? evidence from uruguay. Industrial and Labor Relations Review, 67(1), 202-238.

Burdín, G. \& Dean, A. (2009). New evidence on wages and employment in worker cooperatives compared with capitalist firms. Journal of Comparative Economics, 37(4), 517-533.

Cahuc, P. (2014). Search, flows, job creations and destructions. Labour Economics.

Casacuberta, C., Fachola, G., \& Gandelman, N. (2005). Creación, destrucción y reasignación de empleo y capital en la industria manufacturera. Revista de Economía, 12(2), 89-124.

Clark, A., Knabe, A., \& Rätzel, S. (2010). Boon or bane? others' unemployment, well-being and job insecurity. Labour Economics, 17(1), 52-61.

Craig, B. \& Pencavel, J. (1992). The behavior of worker cooperatives: The plywood companies of the pacific northwest. The American Economic Review, 82(5), 1083-1105. ArticleType: primary_article / Full publication date: Dec., 1992 / Copyright (C) 1992 American Economic Association.

Davis, S. J., Faberman, R. J., \& Haltiwanger, J. (2006). The flow approach to labor markets: New data sources and micro-macro links. Journal of Economic Perspectives, 20(3), 3-26. 
Davis, S. J. \& Haltiwanger, J. (1992). Gross job creation, gross job destruction, and employment reallocation. The Quarterly Journal of Economics, 107(3), 819-863. ArticleType: research-article / Full publication date: Aug., 1992 / Copyright (C) 1992 Oxford University Press.

Davis, S. J., Haltiwanger, J. C., \& Schuh, S. (1998). Job Creation and Destruction. The MIT Press.

Dow, G. K. (2003). Governing the firm: workers' control in theory and practice. Cambridge Univ Press.

Furubotn, E. \& Wiggins, S. (1984). Plant closings, worker reallocation costs and efficiency gains to labor representation on boards of directors. Journal of Institutional and Theoretical Economics, 140 .

Gomez-Salvador, R., Messina, J., \& Vallanti, G. (2004). Gross job flows and institutions in europe. Labour Economics, 11(4), 469-485.

Hall, M. \& Purcell, J. (2011). Information and consultation practice across europe five years after the EU directive. Article, Eurofound.

Haltiwanger, J., Jarmin, R. S., \& Miranda, J. (2013). Who creates jobs? small versus large versus young. The Review of Economics and Statistics, 95(2), 347-361.

Haltiwanger, J., Scarpetta, S., \& Schweiger, H. (2014). Cross country differences in job reallocation: The role of industry, firm size and regulations. Labour Economics, 26(C), 11-25.

Jirjahn, U. (2010). Works councils and employment growth in german establishments. Cambridge Journal of Economics, 34.

Moene, K. O. (1989). Strong unions or worker control. In Alternatives to Capitalism. New York: Cambridge University Press.

Neumark, D., Wall, B., \& Zhang, J. (2011). Do small businesses create more jobs? new evidence for the united states from the national establishment time series. The Review of Economics and Statistics, 93(1), 16-29.

Otterbach, S. \& Sousa-Poza, A. (2014). Job insecurity, employability, and health: An analysis for germany across generations. Technical report, FZID Discussion Paper.

Pencavel, J. (2013). Worker cooperatives and democratic governance. In A. Grandori (Ed.), Handbook Of Economic Organization. Edward Elgar Publishing.

Pencavel, J., Pistaferri, L., \& Schivardi, F. (2006). Wages, employment, and capital in capitalist and worker-owned firms. Industrial and Labor Relations Review, 60(1), 23-44. ArticleType: primary_article / Full publication date: Oct., 2006 / Copyright (c) 2006 Cornell University, School of Industrial \& Labor Relations.

Ward, B. (1958). The firm in illyria: Market syndicalism. The American Economic Review, 48(4), 
566-589. ArticleType: primary_article / Full publication date: Sep., 1958 / Copyright (C) 1958 American Economic Association. 


\section{Appendix}

Table 1: Basic Descriptive Statistics

\begin{tabular}{|c|c|c|c|c|}
\hline & \multicolumn{2}{|l|}{1996} & \multicolumn{2}{|l|}{2009} \\
\hline & WMF & $\mathrm{CF}$ & $\mathrm{WC}$ & $\mathrm{CF}$ \\
\hline number of firms & 163 & 45830 & 206 & 54587 \\
\hline avg size & 30.1 & 6.6 & 28.0 & 7.5 \\
\hline sd size & 96.7 & 42.0 & 92.9 & 50.1 \\
\hline avg age & 7.3 & 13.8 & 13.1 & 15.6 \\
\hline sd age & 13.4 & 15.6 & 13.8 & 14.6 \\
\hline industry: & & & & \\
\hline residual & $5.5 \%$ & $37.0 \%$ & $11.8 \%$ & $38.7 \%$ \\
\hline manufacturing & $15.4 \%$ & $14.0 \%$ & $19.1 \%$ & $10.7 \%$ \\
\hline transport & $64.2 \%$ & $10.3 \%$ & $34.7 \%$ & $12.4 \%$ \\
\hline services & $14.9 \%$ & $38.6 \%$ & $34.3 \%$ & $38.2 \%$ \\
\hline employees/members ratio & $7.0 \%$ & - & $13.0 \%$ & - \\
\hline
\end{tabular}

Table 2: Monthly Job Flow rates

\begin{tabular}{|c|c|c|c|c|c|c|}
\hline & \multicolumn{2}{|c|}{ Creation } & \multicolumn{2}{|c|}{ Destruction } & \multicolumn{2}{|c|}{ Net } \\
\hline & CFs & WMFs & CFs & WMFs & CFs & WMFs \\
\hline total & 3.95 & 1.61 & 3.64 & 1.44 & 0.30 & 0.17 \\
\hline due to enter and exit of firms & 0.63 & 0.48 & 0.57 & 0.34 & 0.06 & 0.13 \\
\hline 1996-1998 & 0.70 & 0.41 & 0.50 & 0.26 & 0.20 & 0.15 \\
\hline 1999-2002 & 0.61 & 0.54 & 0.65 & 0.23 & -0.04 & 0.32 \\
\hline 2003-2009 & 0.62 & 0.46 & 0.55 & 0.43 & 0.07 & 0.03 \\
\hline excluding enter and exit of firms & 3.31 & 1.14 & 3.08 & 1.10 & 0.24 & 0.03 \\
\hline 1996-1998 & 2.99 & 0.82 & 2.72 & 0.95 & 0.27 & -0.14 \\
\hline 1999-2002 & 2.69 & 0.71 & 2.90 & 0.89 & -0.22 & -0.18 \\
\hline 2003-2009 & 3.74 & 1.47 & 3.28 & 1.26 & 0.46 & 0.21 \\
\hline \multicolumn{7}{|l|}{ by sector } \\
\hline residual & 5.09 & 4.79 & 4.76 & 4.26 & 0.33 & 0.53 \\
\hline manufacturing & 2.96 & 2.61 & 2.91 & 2.23 & 0.05 & 0.38 \\
\hline transport & 5.14 & 0.49 & 4.74 & 0.59 & 0.40 & -0.10 \\
\hline services & 3.52 & 3.99 & 3.12 & 3.12 & 0.40 & 0.87 \\
\hline
\end{tabular}


Figure 1: Net Job Creation rates by type of firm.

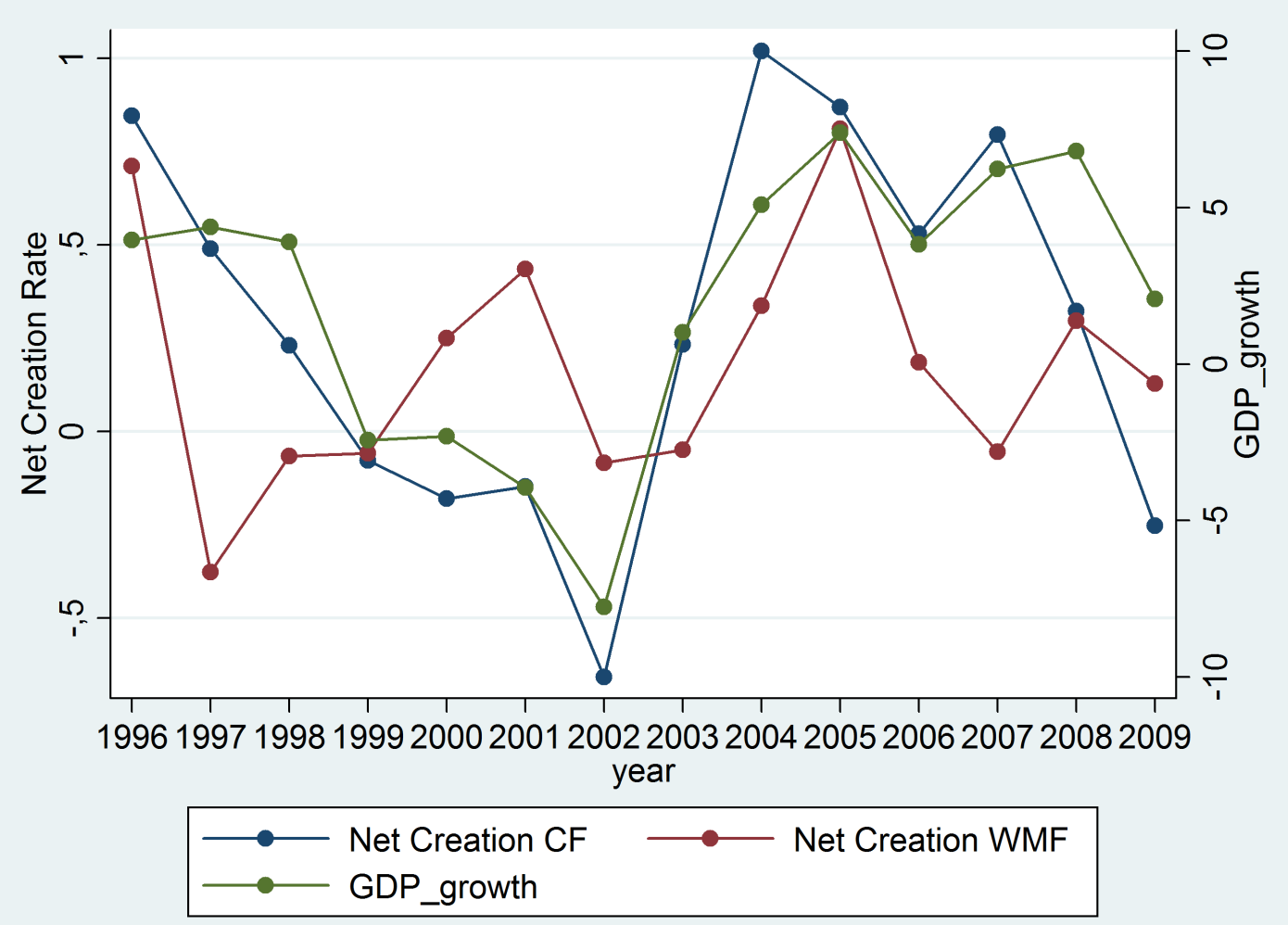

Net creation rates are anual averages of monthly rates. 
Figure 2: Gross Job Creation and Destruction rates by type of firm.

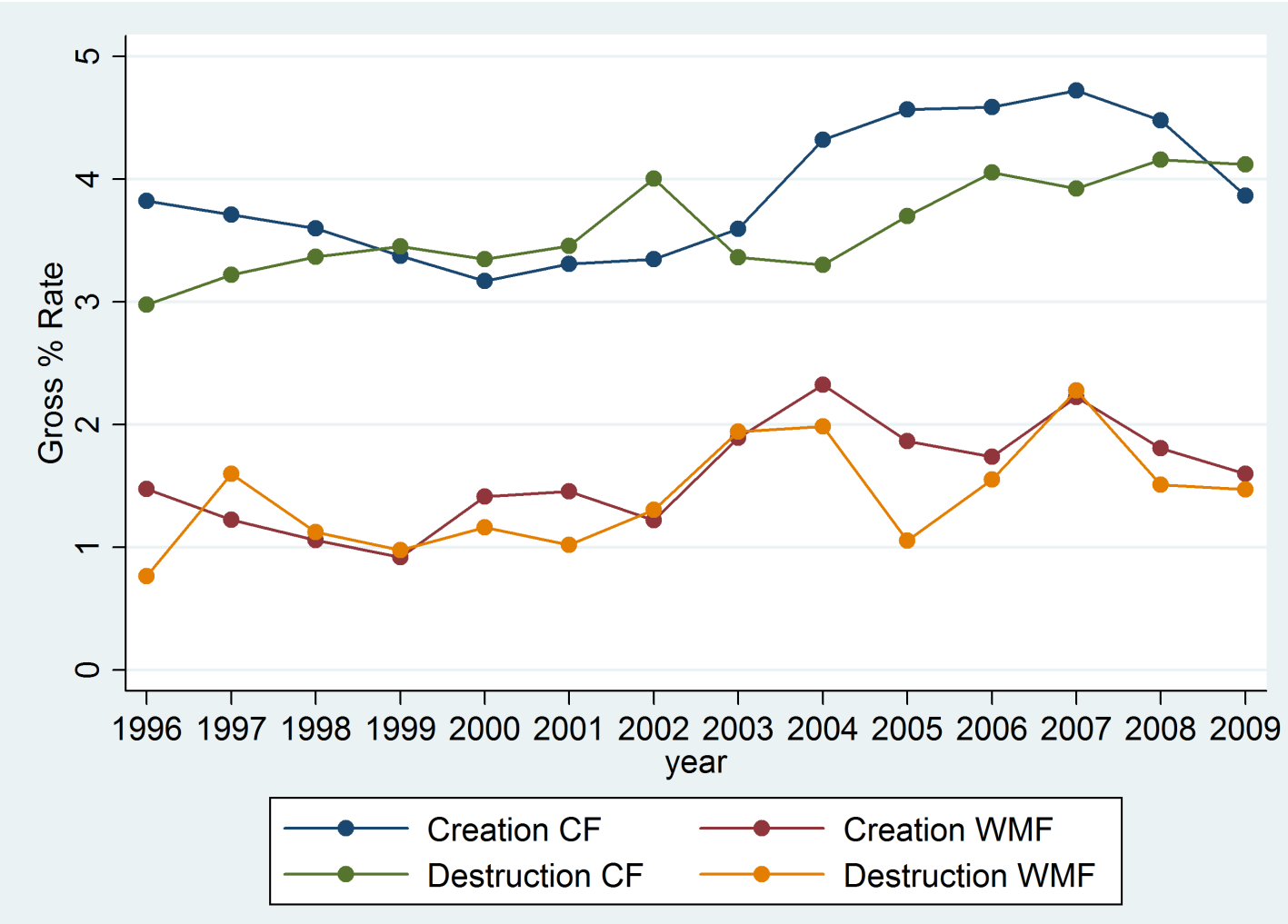

Rates are anual averages of monthly rates. 
Figure 3: Gross Job Creation and Destruction rates for members vs employees in WMFs.

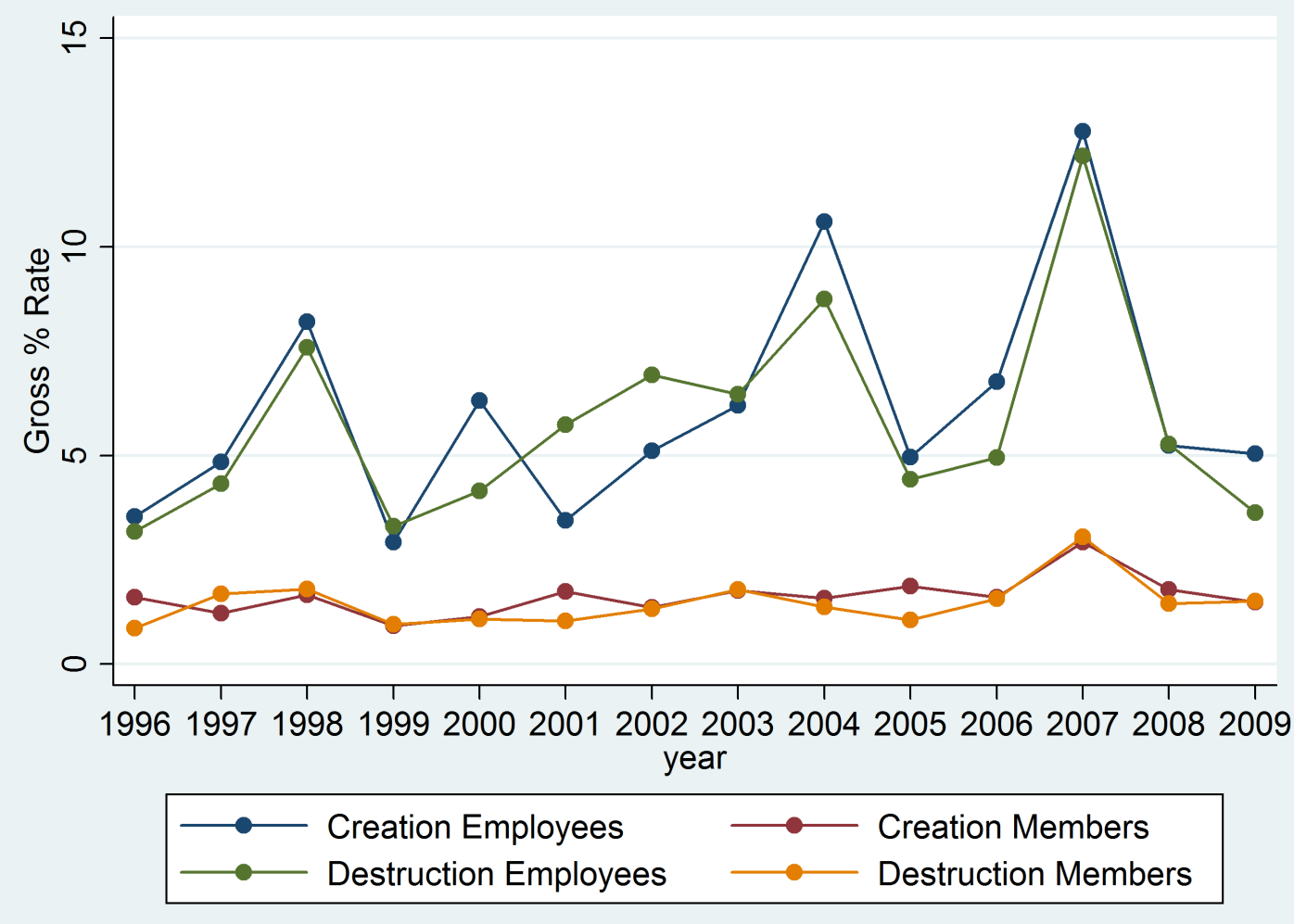

Rates are anual averages of monthly rates. 
Figure 4: Net Job Creation rates by type of firm and Age.

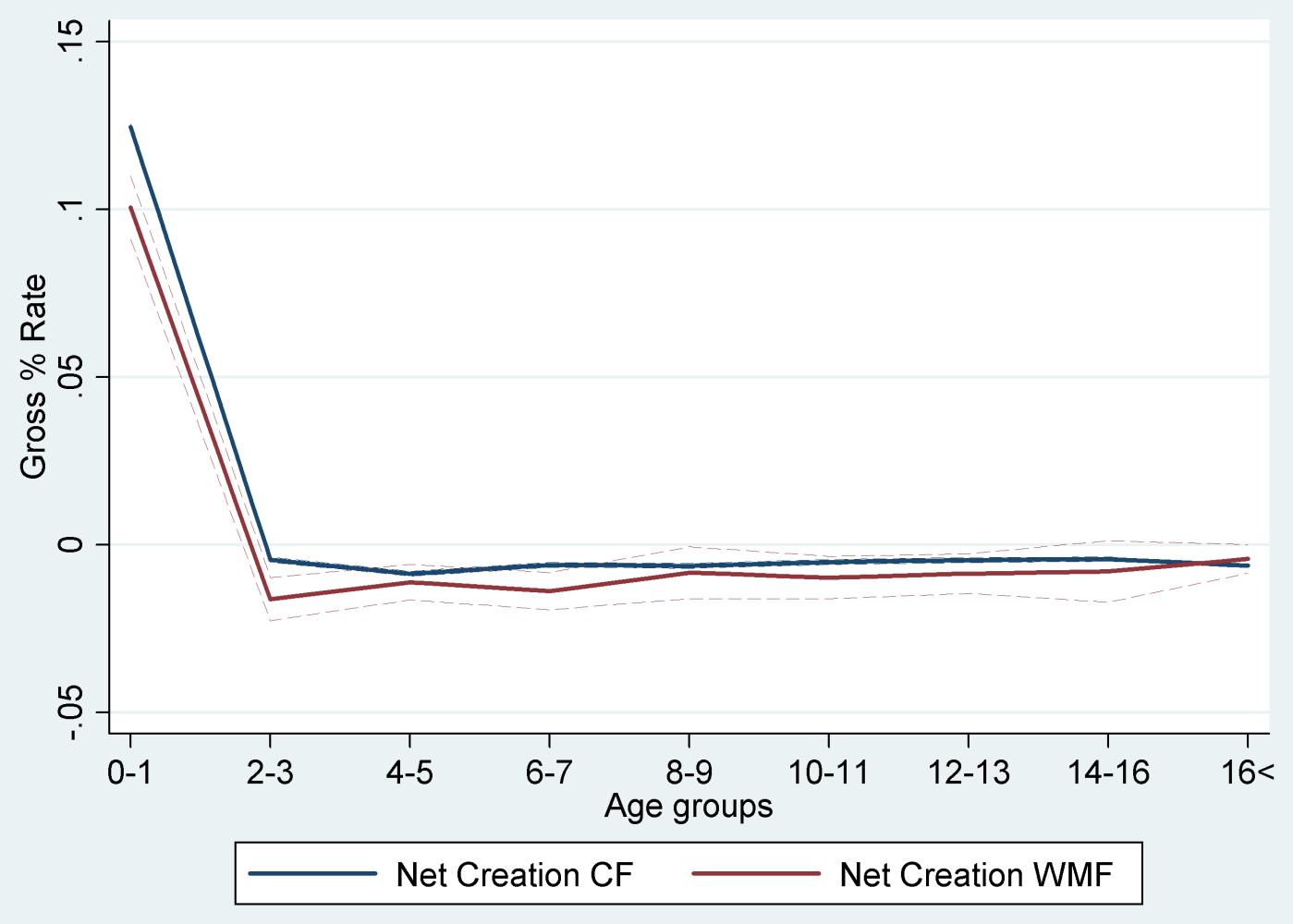

Monthly rates. 
Figure 5: Gross Job Creation and Destruction rates by type of firm and Age.

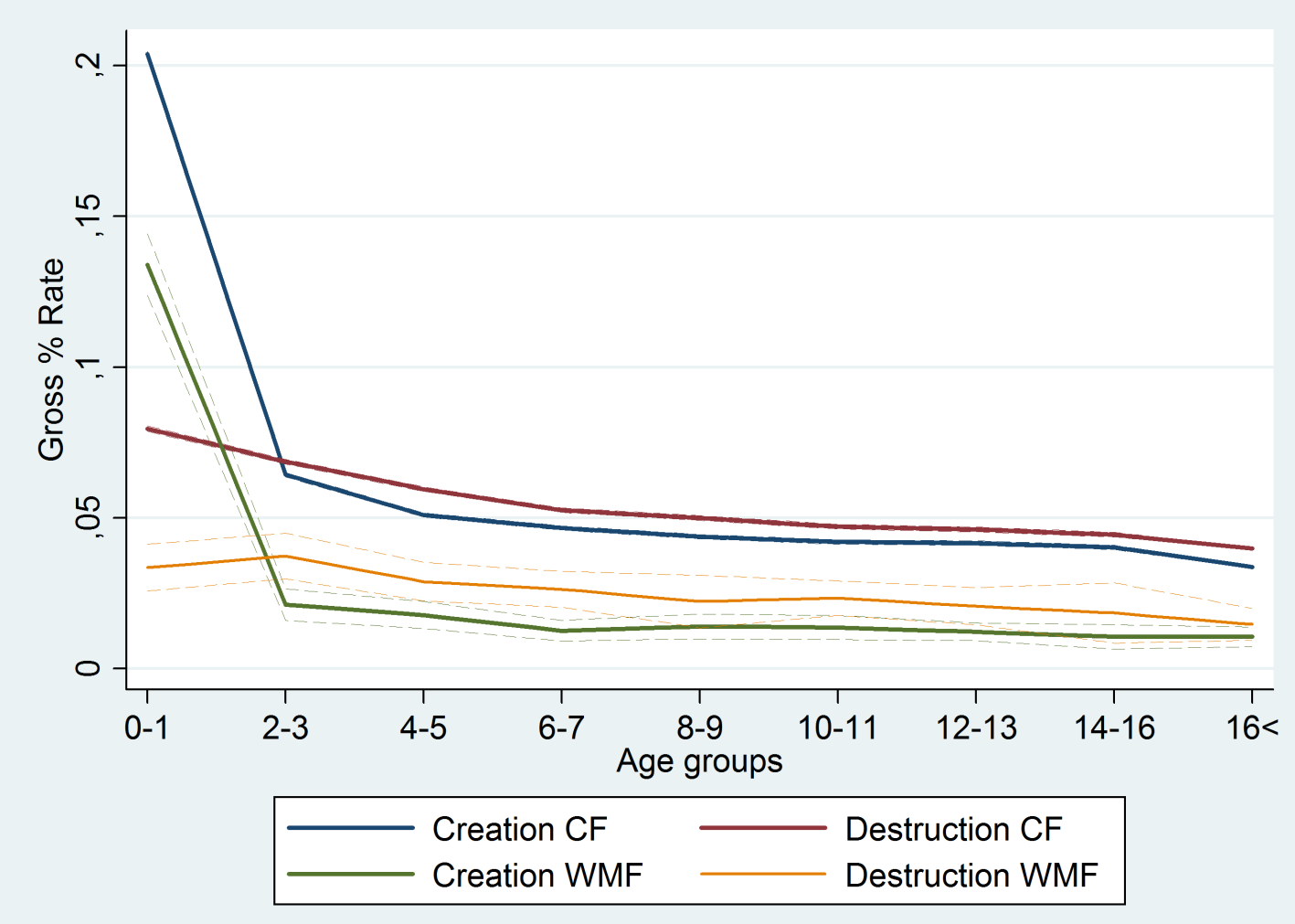

Monthly rates. 
Figure 6: Net Job Creation rates by Worker status in WMF and Age.

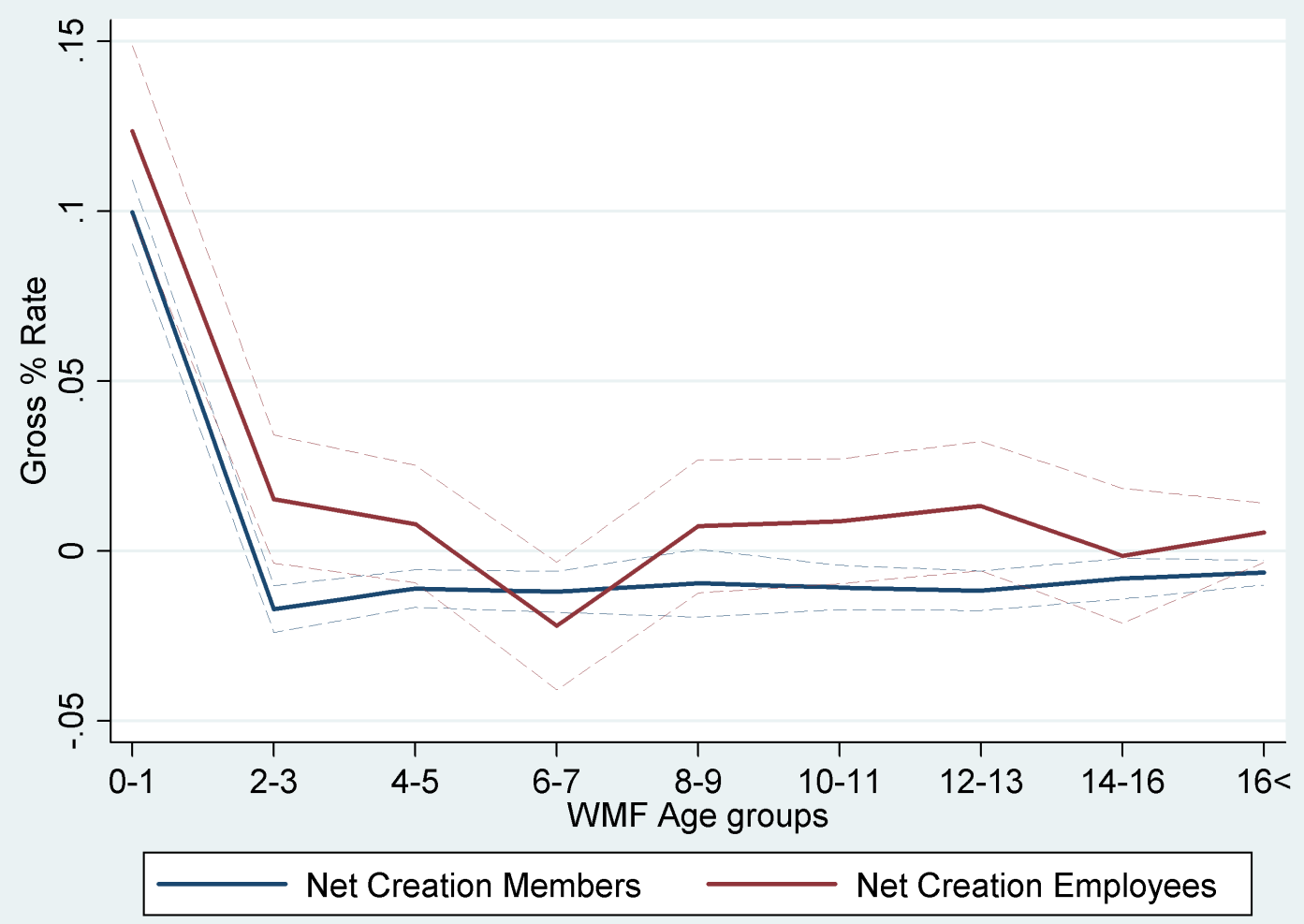

Monthly rates. 
Figure 7: Gross Job Creation and Destruction rates by Worker status in WMF and Age.

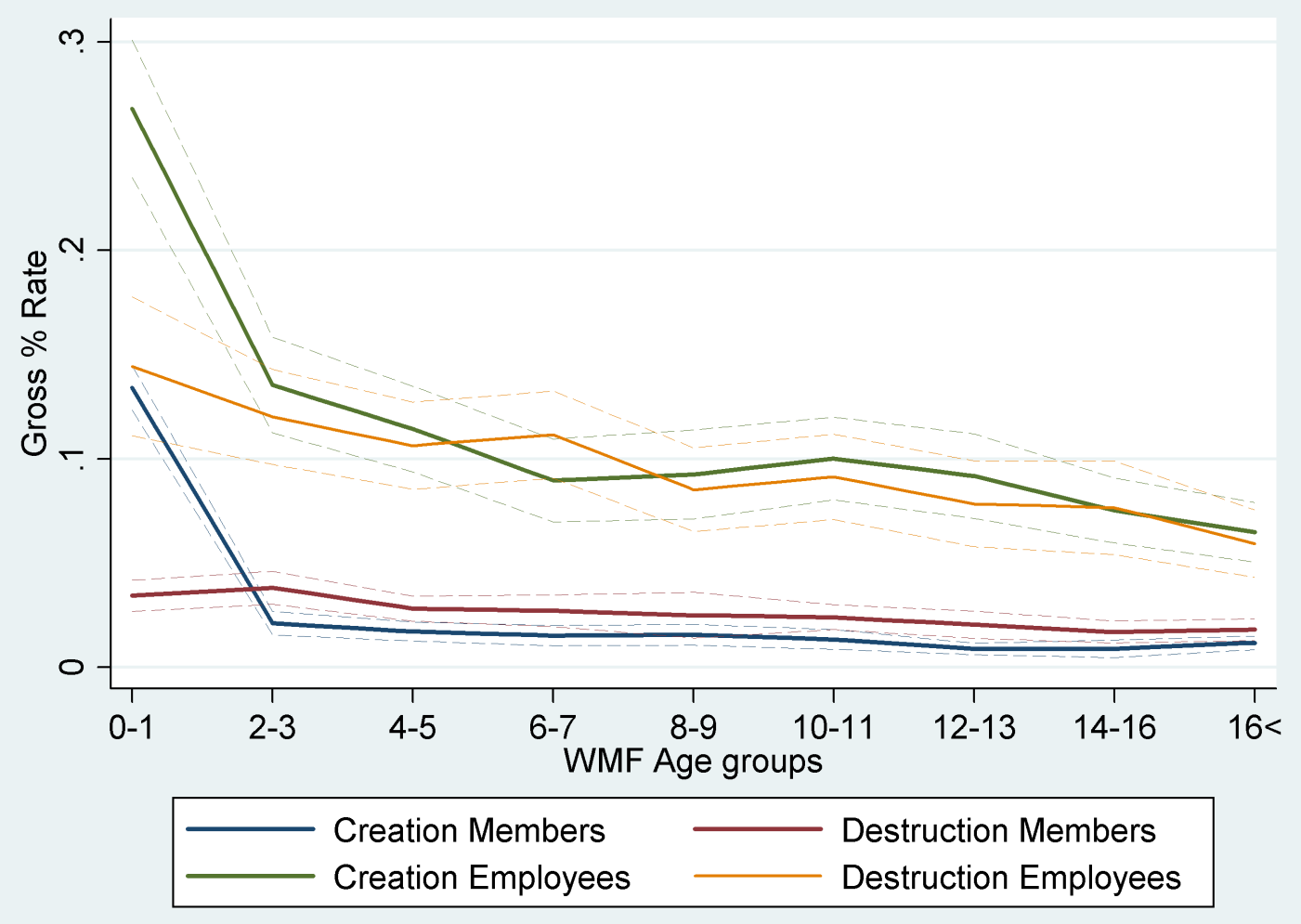

Monthly rates. 
Table 3: Regression Results

\begin{tabular}{|c|c|c|c|c|c|c|}
\hline Dep. Var. & Net & Creation & Destruction & Net & Creation & Destruction \\
\hline Age & $\begin{array}{l}-0.016^{* * *} \\
(0.000)\end{array}$ & $\begin{array}{l}-0.026^{* * *} \\
(0.000)\end{array}$ & $\begin{array}{l}-0.009^{* * *} \\
(0.000)\end{array}$ & $\begin{array}{l}-0.118^{* * *} \\
(0.001)\end{array}$ & $\begin{array}{l}-0.097^{* * *} \\
(0.001)\end{array}$ & $\begin{array}{l}0.020^{* * *} \\
(0.000)\end{array}$ \\
\hline Age2 & $\begin{array}{l}0.000^{* * *} \\
(0.000)\end{array}$ & $\begin{array}{l}0.000^{* * *} \\
(0.000)\end{array}$ & $\begin{array}{l}0.000^{* * *} \\
(0.000)\end{array}$ & $\begin{array}{l}0.001^{* * *} \\
(0.000)\end{array}$ & $\begin{array}{l}0.001^{* * *} \\
(0.000)\end{array}$ & $\begin{array}{l}-0.000^{* * *} \\
(0.000)\end{array}$ \\
\hline Age*WMF & $\begin{array}{l}-0.000 \\
(0.002)\end{array}$ & $\begin{array}{l}0.001 \\
(0.003)\end{array}$ & $\begin{array}{l}0.002 \\
(0.002)\end{array}$ & & & \\
\hline Age ${ }^{*} \mathrm{WMF}$ & $\begin{array}{l}0.000 \\
(0.000)\end{array}$ & $\begin{array}{l}-0.000 \\
(0.000)\end{array}$ & $\begin{array}{l}-0.000 \\
(0.000)\end{array}$ & & & \\
\hline Size & $\begin{array}{l}0.000^{* * *} \\
(0.000)\end{array}$ & $\begin{array}{l}0.001 * * * \\
(0.000)\end{array}$ & $\begin{array}{l}0.001^{* * *} \\
(0.000)\end{array}$ & $\begin{array}{l}0.001^{* * *} \\
(0.000)\end{array}$ & $\begin{array}{l}0.000 \\
(0.000)\end{array}$ & $\begin{array}{l}-0.001^{* *} \\
(0.000)\end{array}$ \\
\hline Size2 & $\begin{array}{l}-0.000^{* * *} \\
(0.000)\end{array}$ & $\begin{array}{l}-0.000^{* * *} \\
(0.000)\end{array}$ & $\begin{array}{l}-0.000^{* * *} \\
(0.000)\end{array}$ & $\begin{array}{l}-0.000^{* *} \\
(0.000)\end{array}$ & $\begin{array}{l}0.000 \\
(0.000)\end{array}$ & $\begin{array}{l}0.000^{* * *} * \\
(0.000)\end{array}$ \\
\hline Size*WMF & $\begin{array}{l}0.001^{* * *} \\
(0.000)\end{array}$ & $\begin{array}{l}0.001^{* *} \\
(0.001)\end{array}$ & $\begin{array}{l}0.000 \\
(0.001)\end{array}$ & & & \\
\hline Size ${ }^{*} \mathrm{WMF}$ & $\begin{array}{l}-0.000^{* * *} \\
(0.000)\end{array}$ & $\begin{array}{l}-0.000^{* * *} \\
(0.000)\end{array}$ & $\begin{array}{l}-0.000 \\
(0.000)\end{array}$ & & & \\
\hline Manufacturing & $\begin{array}{l}-0.031^{* * *} \\
(0.002)\end{array}$ & $\begin{array}{l}-0.003 \\
(0.005)\end{array}$ & $\begin{array}{l}0.028^{* * *} \\
(0.004)\end{array}$ & & & \\
\hline Transport & $\begin{array}{l}0.022^{* * *} \\
(0.002)\end{array}$ & $\begin{array}{l}0.032^{* * *} \\
(0.005)\end{array}$ & $\begin{array}{l}0.010^{* *} \\
(0.004)\end{array}$ & & & \\
\hline Services & $\begin{array}{l}-0.022^{* * *} \\
(0.001)\end{array}$ & $\begin{array}{l}-0.024^{* * *} \\
(0.003)\end{array}$ & $\begin{array}{l}-0.002 \\
(0.003)\end{array}$ & & & \\
\hline WMF & $\begin{array}{l}-0.142^{* * *} \\
(0.017)\end{array}$ & $\begin{array}{l}-0.352^{* * *} \\
(0.024)\end{array}$ & $\begin{array}{l}-0.210^{* * *} \\
(0.017)\end{array}$ & & & \\
\hline Obs & $7,775,872$ & $7,775,872$ & $7,775,872$ & 791,583 & 791,583 & 791,583 \\
\hline R-sq & 0.029 & 0.057 & 0.017 & 0.076 & 0.066 & 0.007 \\
\hline $\begin{array}{l}\text { Fixed Eff } \\
N \text { of } j\end{array}$ & No & No & No & $\begin{array}{l}\text { Yes } \\
137,298\end{array}$ & $\begin{array}{l}\text { Yes } \\
137,298\end{array}$ & $\begin{array}{l}\text { Yes } \\
137,298\end{array}$ \\
\hline
\end{tabular}

